\title{
Brazil and China in Mozambican Agriculture: Emerging Insights from the Field
}

\author{
Sérgio Chichava, Jimena Duran, Lídia Cabral, Alex Shankland, \\ Lila Buckley, Tang Lixia and Zhang Yue
}

\begin{abstract}
Mozambique, a country undergoing rapid transformations driven by the recent discovery of mineral resources, is one of the top destinations for Chinese and Brazilian cooperation and investment in Africa. This article provides an account of the policies, narratives, operational modalities and underlying motivations of Brazilian and Chinese development cooperation in Mozambique. It is particularly interested in understanding how the engagements are perceived and talked about, what drives them and what formal and informal relations are emerging at the level of particular exchanges. The article draws on three cases (1) ProSavana, Brazil's current flagship programme in Mozambique, which aims to transform the country's savanna, spreading along the Nacala corridor, drawing on Brazil's own experience in the Cerrado; (2) the Chinese Agricultural Technology Demonstration Centre (ATDC); and (3) a private Chinese rice investment project in the Xai-Xai irrigation scheme, which builds on a technical cooperation initiative. Commonalities and differences between the Brazilian and Chinese approaches are discussed.
\end{abstract}

\section{Introduction}

Since Mozambique's independence in 1975, official policy discourse has unremittingly represented agriculture as the backbone of the economy. The sector is the main source of livelihoods for about 80 per cent of the active population and its contribution to Gross Domestic Product (GDP) (23 per cent in 2010) remains significant (MINAG 2010a: 4), despite the rapid expansion of the mining and energy sectors. Yet the country's enormous agricultural potential remains largely untapped. Of its 36 million hectares of arable land, distributed across ten different agro-ecological zones, only 10 per cent are farmed and only 50,000 hectares are currently irrigated, 60 per cent of which are in sugar cane plantations (MINAG 2010a: 4).

The devastating effects of civil war, the poor infrastructural base, low productivity levels, vulnerability to extreme weather events, limited investment and weak institutional capacity are amongst the factors frequently offered as explanations for disappointing performance.
Rosário (2012) emphasises instead the political motivations underlying agricultural governance, arguing that private interests and electoral objectives have been key drivers of policy decisions that have failed to produce developmental outcomes for the majority of the rural population. Despite some success stories, mostly in cash crop sectors (such as sugar, cashew nuts, tobacco and horticulture), the dominant smallholder sector remains poor, vulnerable and dependent on subsidised inputs from the state.

After the end of the civil war in 1992, Mozambique quickly become flooded with development assistance and eventually emerged, towards the end of the 1990s, as one of Africa's largest most aid-dependent countries.

Agriculture has traditionally been one of the largest aid-receiving sectors and the sector was for several years supported by a pool-fund mechanism aimed to build the institutional capacity of the agricultural ministry and improve aid coordination in a highly donor-populated sector. Recently, donor coordination initiatives 
have become somewhat discredited, due to failure to show tangible results on the ground, a less positive attitude towards foreign aid by the current government leadership, and the emergence of alternative development cooperation partners, such as China and Brazil.

The first two parts of the article describe the emerging engagements between Mozambique and Brazil and China in the agriculture sector. Next the article analyses policy discourses, imaginaries of agriculture and development and the interests of actors and networks playing out in such encounters. The article draws on empirical material collected through participant observation and key informant interviews undertaken between 2011 and 2012.'

\section{Brazil in Mozambique}

Mozambique occupies a prominent position in Africa-Brazil relations, which stems from a combination of historical affinities, common language, diplomatic bonds and, increasingly, business opportunities (Cabral et al., this IDS Bulletin). It is the top beneficiary of Brazilian technical cooperation programmes in Africa (Cabral et al., this IDS Bulletin). At the end of 2011, Brazil's technical cooperation portfolio in Mozambique comprised 21 active projects, with nine new projects in the process of negotiation. ${ }^{2}$ Agriculture, education and health are the main areas of focus, taking the number of active projects as the measurement criteria (ABC 2010).

Apart from technical cooperation, Mozambique is also an increasingly important destination for Brazilian private capital, particularly in mining and construction. Vale, the second largest mining company in the world, has a coal mining concession at Moatize, Tete Province, and has recently been the focus of attention due to a controversial population relocation away from the mining site. Camargo Correa, Odebrecht and Andrade Gutierrez also have significant presences. Brazil's National Economic and Social Development Bank has been playing a central role in expanding Brazilian businesses and promoting Brazilian exports in Africa (CINDES 2011). Trade between Brazil and Mozambique has, as a result, been displaying an increasingly upward trend. ${ }^{3}$

The importance of Mozambique for Brazilian cooperation is shown by the creation by the
Brazilian Cooperation Agency (ABC) of a Maputo-based coordinator post to oversee all agriculture-related projects in the country, a pilot initiative for Brazilian cooperation more generally. Mozambique also hosts the largest number of researchers from the Brazilian Agricultural Research Corporation (Embrapa) in Africa and the corporation has also appointed a general coordinator based in the country to oversee Embrapa-led projects. Embrapa is hosted by the Mozambican Institute for Agrarian Research (IIAM), an institution under the Ministry of Agriculture (MINAG) and Brazil's main Mozambican counterpart for agriculturerelated projects.

A number of patterns are noticeable. First is the diversity of institutions involved. Unsurprisingly, Embrapa is the dominant Brazilian cooperating institution, with several of its research units involved in project implementation. Others have recently joined the agricultural cooperation domain, including government agencies, such as the Ministry of Agrarian Development (MDA), the Ministry of Social Development (MDS), and the General Secretariat of the Presidency, as well as Brazilian social movements, such as the Popular Peasant Movement and the Peasant Women's Movement, each with different objectives and visions.

Second is the move from one-off training initiatives towards programmes with a longer timeframe and a more systemic approach to capacity building, the so-called 'structural cooperation' programmes. The largest of this type at the moment in agriculture is ProSavana, a programme that has been subject to much attention and controversy.

Third is the transfer into Africa of Brazil's own agricultural policies, or elements of those policies. ProSavana, More Food Africa and the Food Acquisition programme are all examples of cooperation programmes aiming to reproduce Brazil's own policy experiments with agricultural development, for which claims of domestic success have been made (Cabral et al., this IDS Bulletin).

Fourth is the establishment of triangular cooperation arrangements, whereby Brazil partners with traditional donors in providing cooperation to Mozambique. The Japanese Development Cooperation Agency (JICA) and 


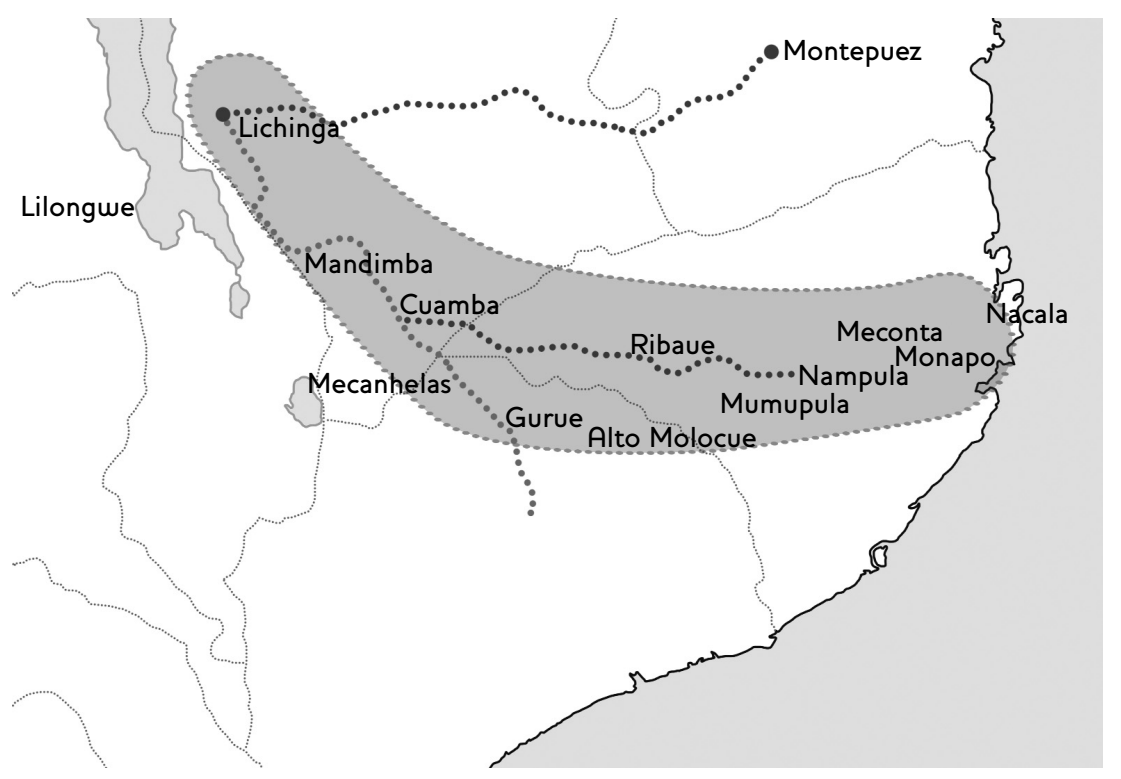

Source Bias (2012).

the United States Agency for International Development (USAID) are thus far Brazil's main trilateral cooperation partners for agricultural projects. The UN's World Food Programme (WFP) and Food and Agriculture Organization (FAO) are also expected to be working with Brazil in the multi-country Food Acquisition programme. In addition to creating a platform for synergies in technical expertise, trilateral cooperation also allows Brazilian technical cooperation to be complemented by financial cooperation provided by traditional donors.

The final observed trend is the gradual permeation of private interests and capital into development cooperation initiatives in the agricultural sector. As noted above, More Food Africa is an example of this. The creation of the Nacala Fund (see below), which seeks to mobilise Brazilian and Japanese capital into the region that ProSavana is targeting, is another manifestation. ProSavana itself is targeting a region whose principal strategic economic importance is as an export corridor for the output of Brazilian mining operations in landlocked Tete Province.

\subsection{The case of ProSavana}

ProSavana is perhaps the most ambitious and high-profile initiative in the recent history of Brazil's development cooperation in Africa. The programme has been described by the media as an example of 'Brazil's neo-colonialism in Africa' (Rafael 2011) and of how Mozambique is set to become 'Brazil's new agricultural frontier' (Folha de São Paulo 2011). ProSavana is expected to cover 14 million hectares of land along the Nacala corridor, an area spreading across three provinces of northern Mozambique (Niassa, Nampula and Zambézia), to reshape the region's economic landscape and transform it into a highly productive region addressing food security issues (Figure 1).

ProSavana is inspired by the development experience of the Brazilian tropical savanna (known as Cerrado), accomplished through, inter alia, Prodecer, a 30-year cooperation programme between Japan and Brazil. This programme is credited with transforming the Cerrado into one of the most productive regions in the country, and for turning Brazil into a leading global producer of soybeans (Hosono and Hongo 2012). ProSavana is being implemented through a triangular partnership between Japan, Brazil and Mozambique. As a trilateral programme, it is justified as a 'win-win-win' cooperation initiative (JICA and Oriental Consultants 2011).

ProSavana envisages supporting both commercial and smallholder agriculture production systems, of large and small scale, largely through research and extension, drawing on Brazil and Japan's 
experiences and technologies. The programme has three main components (Embrapa 2012):

(1) ProSavana-Projecto de Investigação

(ProSavana-PI), launched in 2011 and focusing on reinforcing IIAM's research and institutional capacities; (2) ProSavana-Projecto de Extensão (ProSavana-PE) to be launched during 2013 and emphasising training and extension, and including pilot productive projects for small and commercial growers; and (3) ProSavana-Plano Director (ProSavana-PD), launched in 2012 and aimed at producing an integrated agro-industrial master plan for the area, looking not only at agricultural production and productivity, but also at broader regional development issues, such as infrastructure and markets.

This latter component is laying the groundwork for Brazilian and Japanese private investment in agriculture in the region, although ProSavana itself does not include any such investments. The subcontracting of Getúlio Vargas Projects (GV-Projetos), the consultancy arm of a wellknown Brazilian business school, Getúlio Vargas Foundation, to oversee implementation of ProSavana-PD constitutes a new practice in Brazilian cooperation.

Since the launch of ProSavana, promotional activities have taken place in Brazil, Japan and Mozambique. For example, the event

'Agribusiness in Mozambique: International Cooperation Brazil-Japan and the Investment Opportunities', that took place in Brazil in 2011, attracted some high-profile participants from the Mozambican and Brazilian governments, as well as some influential representatives from Brazil's agri-business (such as the President of the Agriculture and Livestock Confederation of Brazil (CNA), Senator Katia Abreu and the President of the Higher Council of Agribusiness from the São Paulo State Federation of Industries). Brazilian and Japanese entrepreneurs were also present, including Mitsubishi Co. (Loureiro 2012). Another event on 'Investment Opportunities in Mozambican Agri-business' was held at the Federation of Agriculture and Livestock of Mato Grosso in Cuiabá, organised by the Mato Grosso Association of Cotton Producers (AMPA), ABC and the Brazilian Ministry of Foreign Affairs (AMPA 2011).

More than 100 farmers, especially from the Brazilian state of Mato Grosso, are reported to have visited Mozambique in recent years. In 2010, Senator Kátia Abreu led a visit in her capacity as president of the CNA. ${ }^{4}$ According to one view, Brazilian farmers are keen to come to Mozambique because of the low cost of land as compared to Brazil, the incentives offered by the Brazilian government within ProSavana, the opportunities offered by the Nacala Fund and Mozambique's location with its easy access to Asian markets. ${ }^{5}$ The head of AMPA has also referred to the lack of stringent environmental regulations in Mozambique as an incentive to invest (Folha de São Paulo 2011). Whether or not a wave of exclusively Brazilian land deals is imminent, Brazilian managers are already a feature of Zimbabwean- and Mozambican-owned commercial farms in the Nacala corridor region, and Brazilian investors have begun to form joint ventures with Mozambican and Portuguese agribusiness concerns like Agromoz, which recently began soybean, cotton and maize operations in the Gurué district of Zambézia. ${ }^{6}$

The Nacala Fund, a private fund aiming to mobilise capital in Brazil and Japan to support agri-business projects along the Nacala corridor, is expected to attract around US\$2 billion to support large-scale production systems through the creation of associations led by Brazilian farmers, who will work with Mozambican farmers to transfer expertise and strengthen capacity, as well as integrating smallholders into value chains. ${ }^{7}$ The Fund was launched in 2012 at high-profile events in Brasília and Maputo which had significant Brazilian and Mozambican government participation, despite its ostensibly private sector identity. It has already received expressions of interest from major Brazilian and Japanese conglomerates, such as Votorantim and Sumitomo, and is currently being promoted through a series of roadshows with the aim of being fully subscribed by the time the ProSavana Master Plan is due in July $2013 .{ }^{\circ}$

The Fund for ProSavana's Development Initiative was set up in September 2012 in Nampula, as a bilateral initiative between Mozambique and Japan, to support different pilot models for the integration of smallholders into selected value chains. Like the Nacala Fund, this is a parallel initiative that is not formally part of ProSavana. An initial budget of US $\$ 750,000$ (Chichava et al. 2013) and a first credit package of MZN11.5 million (New 


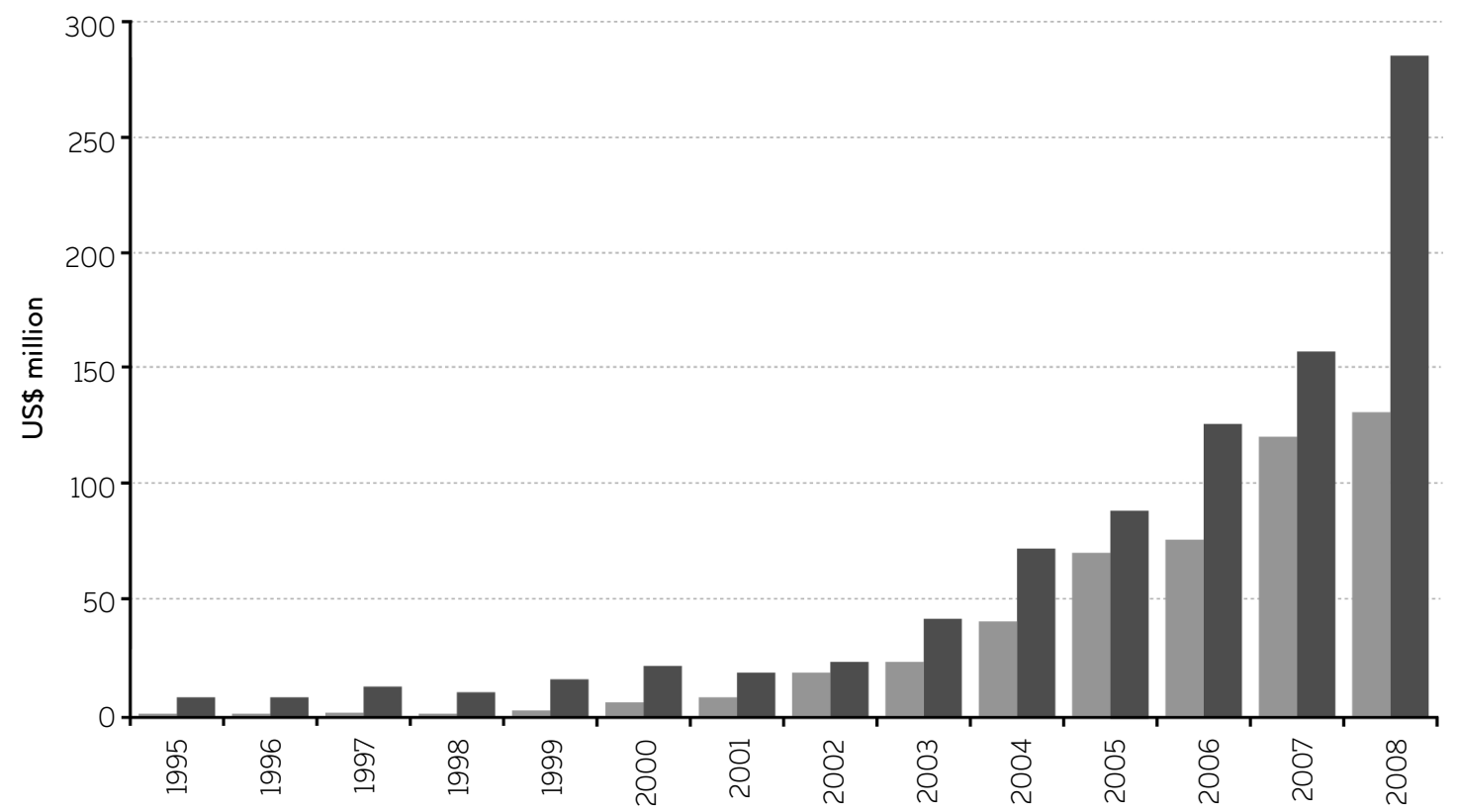

China's imports from Mozambique

China's exports from Mozambique

Source Centre for Chinese Studies (2009), using data from the World Trade Atlas.

Mozambican Metical) (US\$390,000) have already been approved to fund the activities of several companies operating in the Nacala corridor (Chichava et al. 2013). Loans to these companies will be offered at an interest rate of up to 10 per cent and they have to commit to integrate smallholders through contract farming and not as waged labourers. Besides the loan, these companies will benefit from technical assistance from MINAG, JICA and GAPI-SI, a Mozambican financial institution supporting business development (Chichava et al. 2013).

\subsection{Local expectations and perceptions}

ProSavana has been both praised and strongly criticised in Mozambique. Its perceived importance for Mozambican government actors is shown by the fact that it has attracted several senior MINAG officials - the programme's director is the former director of IIAM, and the former director of MINAG's International Cooperation Department has been hired as an adviser. Mozambican political and business elites look forward to replicating the Cerrado experience, as well as emulating Embrapa's role as a worldleading agricultural research corporation. They are also enthusiastic about the prospective inflow of private investment and the modernisation of agriculture, both because it is seen as representing the fulfilment of the modernisation discourse prevalent in Mozambican debate, and because of the opportunities for individual as well as collective economic benefit. One Mozambican journalist has argued that ProSavana serves the private interests of members of the ruling party (Mabunda 2012). ProSavana's combination of technology transfer and private capital is contrasted with traditional aid projects where private capital mobilisation is often not sufficiently taken into account.

Givil society has, on the other hand, voiced concerns about potential negative impacts, in terms of social inclusion as well as environmental sustainability. The Mozambican National Peasants' Union (UNAG) has recently accused ProSavana of being top-down and failing to involve farmers and civil society in a meaningful way (UNAC 2012). It has also warned about the danger of creating a wave of landlessness in the country, impoverishing rural communities by making them dependent on large-scale investments, and damaging the environment and compromising sustainability. There has also been 
much speculation in the media about the interests ProSavana is serving (Loureiro 2012; Rafael 2011).

\section{China in Mozambique}

China's relationship with Mozambique reaches back several decades. During Mozambique's struggle for independence in the 1960s, China provided political, economic and military support for the Liberation Front of Mozambique, Frelimo (Centre for Chinese Studies 2009). In 1975, when Mozambique gained independence, China established formal diplomatic relations with the country. Since then, China and Mozambique have conducted frequent high-level exchanges and maintained a friendly cooperative relationship. Agricultural development partnerships take place in the context of wider economic, trade and investment relations, although there is no evidence of a widespread Chinese 'land grab' as suggested by some (Brautigam and Ekman 2012). Figure 2 shows that the volume of trade between China and Mozambique experienced significant and rapid growth over the past decade.

Since 2007, China has been among the top ten investors in Mozambique. In 2010, Chinese investments in industry accounted for 71 per cent of total investments, with investments in construction, services, agriculture and agroindustry representing 21 per cent, 6 per cent and 2 per cent respectively. Investments by Chinese entrepreneurs in southern Mozambique (Maputo Province and Maputo City) accounted for more than 85 per cent of the total. ${ }^{9}$

Under the framework of the Forum on ChinaAfrica Cooperation (FOCAC), China announced the exemption of debts of RMB294 million (Renminbi) (US\$48) as of the end of 2005. ${ }^{10}$

Mozambique also borrowed from the China Exim Bank with the aim of rehabilitating and developing important agricultural infrastructure in regions considered critical to boosting the agriculture sector. ${ }^{11}$ This included a US\$50 million concessional loan, the first US $\$ 30$ million tranche of which was placed under the management of the Office of the Zambezi Development Plan (GPZ) and was used to build three agro-processing factories (cotton, rice and maize) in Manica, Zambezia and Tete Provinces respectively (MINAG 2010b). The remaining
US\$20 million was used to import agricultural equipment from China. The overall aim was to help improve local farmers' production, with the intention of providing production for the factories. In 2012, Mozambique signed another long-term credit line of US $\$ 60$ million to develop the Chokwe Agro-Processing Complex. The project aims to develop several activities, including a processing, packaging and conservation unit; a cattle breeding and processing farm; rice processing factories; rehabilitating the irrigation system and establishing an irrigation maintenance unit and agricultural service centres (MINAG 2012). In addition, since 2011, Mozambican authorities have been negotiating two loans of US\$25 million and US\$12 million with China Exim Bank in order to rehabilitate the Chipembe and Nguri dams in Cabo Delgado Province (GdM 2011).

These loans and commercial investments are complemented by a series of development cooperation and investment projects. The next two sections highlight two cases.

\subsection{The China Agriculture Technology Demonstration Centre}

At the Beijing Summit of FOCAC in November 2006, President Hu Jintao announced the establishment of ten Agricultural Technology Demonstration Centres (ATDCs) across Africa, as part of eight steps for the consolidation of China-Africa partnerships (FOCAC 2006). The objective of the centres is to perform agricultural demonstrations, rural extension and technical training to boost the productivity of the beneficiary countries and to contribute to food security. There are also diplomatic motivations, accompanied by the idea that aid should generate mutual benefit. For China, economic gains include promoting Chinese agricultural technology in the African market, easing in Chinese investors and expanding trade opportunities.

The ATDC in Mozambique is located in Boane district, southwest of Maputo, occupying 52 hectares of IIAM's Umbeluzi agrarian station. The total production area is 35 hectares of corn, rice and vegetables. The centre cost around US $\$ 6$ million and its operation costs the Chinese government annually about US $\$ 180,000 .{ }^{12}$ It is managed by the Hubei Lianfeng Agricultural Development Corporation, which was running the Hubei-Gaza friendship farm (Triangle of 
Central China 2012). Hubei agricultural companies are encouraged through the 'Going Out' policy (Li et al. 2012), a central driving force of Chinese integration into the global economy for the past decade. Meanwhile, on the Mozambican side, coordination has been compromised due to misunderstandings and power conflicts between MINAG and the Ministry of Sciences and Technology (MCT) (Duran and Chichava 2012).

\subsection{The case of the Xai-Xai irrigation scheme}

The Regadio do Baixo Limpopo (RBL), more commonly known as the Xai-Xai irrigation scheme, is located in Gaza Province and covers an area of 12,000 hectares. It is one of the largest irrigation schemes in the region (Ganho 2012). It was created in 1951, during the colonial period, and after being used for some time after Mozambican independence it was left abandoned for many years. The rehabilitation of the Massingir dam in 2003 brought important infrastructure improvements and institutional and agricultural development. The arrival of Chinese and other investors in Xai-Xai is seen by Mozambican authorities as a new hope in the efforts to boost Mozambican agriculture.

Initial contact between Chinese and Mozambican actors started in 2005 through meetings between the governments of Gaza and Hubei Provinces, and site visits throughout Gaza (Direcção Provincial Agricultura de Gaza 2008). A bilateral agreement specified that a Chinese enterprise from Hubei would establish a rice production project in the Ponela block of the irrigation scheme, and would transfer Chinese rice production technology to local farmers. It also envisaged developing horticultural production in Moamba district, Maputo Province (Direcção Provincial de Agricultura de Gaza 2008). The text of the agreement did not specify what was to be done with the rice produced, what technology would be transferred, and how local beneficiaries would be identified.

According to CPI (Centro do Promoção de Investimentos [Investment Promotion Centre]) data, the project, with a budget of US\$1.2 million, was to be implemented in an area of 300 hectares. However, the agreement between the provincial governments of Gaza and Hubei foresaw that the area covered could reach up to 10,000 hectares (Direcção Provincial de Agricultura de Gaza
2008). The company named to carry out the project was Moçambique Lianfeng

Desenvolvimento de Agricultura Co., Limitada (also referred to as Hubei Lianfeng Mozambique Co. Lda. or HLMO Co.Lda.). It is a subsidiary of Lianfeng Overseas Agricultural Development Co Ltd, a Chinese state-owned enterprise, the same company running the ATDC.

Parallel to these activities, a group of Chinese scientists from the Chinese Academy of Agricultural Sciences (CAAS) visited Xai-Xai in 2008-09 to perform rice yield tests with the support of the Gates Foundation, under the framework of the 'Green Super Rice Program'. Thirty varieties of Chinese hybrid rice and one Mozambican variety, called 'Limpopo rice', were successfully tested (CAAS 2009).

HLMO Co.Lda. never managed to fully develop the 300 hectares granted by the Mozambican government during the five years of activity (Direcção Provincial de Agricultura de Gaza 2010).$^{13}$ According to an evaluation of the project carried out by the provincial government of Gaza, the company was also unable to fulfil other aspects of the bilateral agreement (Direcção Provincial de Agricultura de Gaza 2010). For example, the arrangement had been for HLMO Co.Lda. to help local farmers improve their productivity from original levels of $1-3$ tonnes to 7-10 tonnes per hectare through the transfer of Chinese technology (Direcção Provincial de Agricultura de Gaza 2010). However, upon implementation, payments were required for training services provided, something that had not been mentioned in the original agreement. The majority of local farmers were unable to pay for such services. According to employees of HLMO Co.Lda., technology transfer has failed because Mozambican farmers lack commitment to agriculture. As one of the respondents explained, 'We are here to help farmers, but the farmers are not interested in agriculture'. ${ }^{14}$ This issue remains a main source of local disappointment with Chinese engagement in the region.

In 2012, because of the above difficulties, Wanbao Grain and Oil Investment Limited (WAADL) took over the project. WAADL brings along greater financial muscle and has been granted an area of 20,000 hectares to produce rice and establish agro-processing facilities. A Mozambican source estimates that the 
investment now reaches US $\$ 200$ million, ${ }^{15}$ although a Chinese source talks of US $\$ 95$ million (Danqing and Yongsheng 2012). Hubei authorities consider this to be one of the province's most important overseas investments in agriculture, a shining example of the 'successful "going out" of Hubei agriculture' and winning 'honour for the country' (Hubei Daily 2012).

Even though the activities are still at an early stage, some concerns are beginning to be voiced in the local press, including fears of displacement of farmers and concerns about water management. As with the Brazilian interventions, debates over who wins, and who loses are emerging.

\section{Dimensions of the development encounter}

What then are the emerging features of the Brazil-Mozambique and China-Mozambique encounters, as framed by the selected development cooperation efforts? This section considers narratives of development cooperation, imaginaries of agricultural development and technological modernisation and the underlying motivations of actors involved in these encounters.

\subsection{The Brazil-Mozambique encounter}

Brazil's official discourse favours concepts of 'international cooperation for development', 'technical cooperation' or 'development partner' over conventional terms like 'official development assistance', 'technical assistance' or 'donor' (Cabral et al., this IDS Bulletin; Costa Vaz and Inoue 2007). It stresses that Brazilian projects in Africa are demand-driven - though this is not always the case, especially in the case of triangular projects like ProSavana. Brazil also claims that its limited experience as a provider of international cooperation is an advantage in the sense that 'we are all learning together'. ${ }^{16}$ For example, the Embrapa representative in Maputo states:

Embrapa and Brazilian cooperation are going through a learning and maturing process in Africa. We are defining what Brazilian cooperation for the development of agriculture is. Firstly, we thought of Embrapa Africa, but when we arrived to [sic.] the continent, the demand from the African countries was huge in 2009, I visited 11 African countries - and for this reason we decided to think bigger and to create Embrapa International. Our interests are what are best for our African partners and for Mozambique. ${ }^{17}$
Brazilian professionals working on ProSavana in Mozambique argue that the value added of Brazilian cooperation is the provision of first-hand expertise and technical cooperation without intermediaries. The close relations between Embrapa and Mozambican institutions are portrayed as guaranteeing a more horizontal relationship and better government ownership. The representative of Embrapa in Maputo explains:

Embrapa never works alone. Our partners are always the local research institutions - in the case of Mozambique, IIAM. Because Brazil's interests are the local government's interests, our close working relationships - both government-to-government and local expertsto-Brazilian experts - are a guarantee of that. ${ }^{18}$

The emphasis on the technical character of cooperation in official discourse, however, underplays the importance of commercial and political motivations. Despite adhering to the South-South principle of mutual advantage or shared gains, Brazil presents its cooperation activities as free of commercial interest and, at the highest political level, Brazil's presence in Mozambique and Africa more broadly is framed, especially by Lula, primarily in terms of solidarity and moral debt linked to the slave trade history (Instituto Lula 2012).

Above all, Brazil's own experience strengthens the country's legitimacy as a cooperation partner in developing commercial and family agriculture in Africa and Mozambique. In the words of a senior diplomat at the Brazilian Embassy in Maputo, 'Brazilian cooperation is legitimate because we are bearers of a successful development experience'. ${ }^{19}$ Brazil is often presented as a successful model for the development of agri-business or commercial agriculture as well as family agriculture. For example, the development of the Cerrado has been referred to as 'a miracle' (The Economist 2012) or 'one of the great achievements of agricultural science in the twentieth century' (statement by Dr Norman Borlaug, Nobel Peace Prize winner, quoted in Hosono and Hongo 2012: vii).

Brazil's own versions of the Cerrado narrative not only emphasise the role of agricultural science and the enabling policy environment promoted by a strong state with a long-term development vision, but also a particular social imaginary of 
the 'conquest of the wilderness'. An FGV representative referred to this during a discussion of the objectives and procedures of the Nacala Fund: 'Agriculture is a high-risk economic activity. A way to minimise risks is to bring in people who have the knowledge and experience - and these people are Brazilians. Brazil is recognised worldwide as a global food producer, and the Brazilians know how to do it. In Brazil, for the Cerrado we used to say: "Cerrado, neither given nor inherited"'. ${ }^{20}$ It was worse than the Wild West'. ${ }^{21}$

Seen from the Mozambican side, there are two clashing perceptions of Brazilian cooperation. Government officials, mostly from institutions like MINAG, the Centre for the Promotion of Agriculture (CEPAGRI) or IIAM, portray the Brazilian experience as a successful one. They hope that access to Brazilian technology will help boost agriculture production and productivity and perhaps replicate the Cerrado miracle. According to an official from MINAG:

Brazil has a valuable experience in agriculture. The Brazilians succeed in the tropicalisation of soybean, for example. So, Mozambique is going to acquire Brazilian know-how. Thanks to Brazilian technology, our farmers are going to be stronger and we are going to establish agriculture value chains. ${ }^{22}$

Mozambican government officials also praise the 'win-win' dimension of Brazilian cooperation and are less inclined to downplay the political and commercial agendas. The same official emphasised that:

ProSavana is a highly ambitious programme and the important political and economic mutual interests are a guarantee for its success. For example, today the FAO director is a Brazilian, José Graziano da Silva. For his election, Brazil negotiated with Guebuza the support of Mozambique for his candidacy. Brazil pressured Portuguese-speaking African countries to support Graziano by committing to a South-South cooperation policy. With Brazil, the main objective is technical assistance. For example, with ProSavana we are going to benefit from the Brazilian technical assistance and institutional strengthening of IIAM; our farmers will be stronger; and Japan will support the project financially. Brazilian farmers will be able to come here, where they can expand their production and markets, to sell to China and India. In the end, everything is done with a commercial perspective. ${ }^{23}$

From a different perspective, ProSavana and the enthusiasm around replicating the Cerrado experience have been fiercely criticised by organised civil society inside and outside Mozambique. UNAC, in contact with Brazilian social movements through Vía Campesina, has publicly voiced its concerns (UNAC 2012). Japanese social movements and NGOs are also mobilising around ProSavana. ${ }^{24}$ Such critical voices are supported by arguments emphasising the social and environmental damages of largescale 'agri-business' associated with the Cerrado model (Classen 2013; Weinhold et al. 2011).

Different actors in the Brazil-Mozambique partnership also have different motivations. While IIAM is eager to strengthen connections with Embrapa and perhaps attempt to emulate its institutional model, UNAG, while asserting its position in Mozambique's still amorphous civil society, looks with fascination at Brazil's dynamic rural social movements and the country's history of vigorous political contestation.

\subsection{The China-Mozambique encounter}

Mozambican politicians and elites have been receptive to China's renewed interest in the country. In agriculture there is great enthusiasm about cooperation with China. President Guebuza has stated how China has successful development experience, especially in promoting agriculture and rural development, and emphasised that Mozambique can learn from China to be selfsufficient in grains (Revista Macau 2011). As an official from MINAG explained:

The relation between China and Mozambique has multiple faces. There is the commercial feature on one side and the technology transfer feature on the other. For example, the ATDC in Boane is a project focused on technology transfer and is a donation from the Chinese government. On the other hand, projects like the processing factories in Zambézia or the rice production project in Xai-Xai have a more commercial perspective..$^{25}$

However, perceptions of China's actual engagements in agricultural development in Mozambique are divided. Mozambican 
government officials and elites look at Chinese investments and technical assistance with enthusiasm. China is seen as holding the answer to perceived technological gaps in Mozambique's agriculture. At the ATDC inauguration in 2011, President Guebuza stated: 'The aim is not just [to] increase productivity because it can be done in different ways. Productivity is not always increased by the expansion of the production area. We need to keep in mind the other component of increasing production through the rise of productivity in small areas.' Besides the technology, Chinese work capacity and discipline are highly praised:

Mozambican farmers don't live in the machamba (farm). The Chinese do, they are always there, working. In a Mozambican machambas, for three men there are three beds. The Chinese only have two beds for three men because there has to be someone working. ${ }^{26}$

However, the opinion of lower-rank officials is more cautious and marked by stereotypes and misunderstandings. These are exacerbated by language barriers and cultural differences arising in cooperation with Chinese actors on the ground; these in turn affect the functioning, the relations and the transfer of technology and knowledge. Firstly, language barriers hinder communication among local technicians from IIAM, the day labourers and the beneficiaries of the courses given at the centre. Likewise, there is mistrust among Mozambican technical staff at the centre regarding Chinese knowledge and work conditions: 'The Chinese don't speak Portuguese or English. We don't talk to them. And they say they are agricultural experts but they don't follow the regulations for the chemicals they use. I think there is something wrong in that centre. ${ }^{27}$ One farmer explained, 'I learned some things but at the end everything goes to the garbage because we don't have the means to implement what we learned. ${ }^{28}$

Yet local officials praise highly the work capacity and discipline of Chinese people:

One of the great advantages of the Chinese is their work culture. In Mozambique, the boss stays home and calls the workers to tell them what to do in the machambas; the Chinese boss is different. He is working next to the farmers and workers... So, the Chinese model is made to increase productivity. ${ }^{29}$
In the field, perceptions between Mozambican and Chinese actors are more complex. The Chinese managers of the Xai-Xai rice project and of the ATDC expressed the need to transform the Mozambican way of thinking; according to interviews with Chinese workers at the ATDC, they had been unable to achieve successful cooperation because Mozambicans did not believe it was possible to produce more by working more. Secondly, a Chinese manager at Wanbao criticised the fact that the majority of Mozambicans working in agriculture were involved in a range of off-farm activities and so were not dedicated to agriculture. Mozambican bureaucrats from RBL echoed these sentiments, arguing that Mozambican farmers 'are not committed to the agriculture tasks' and that they therefore 'showed limited interest to learn from the Chinese' (Chichava forthcoming).

\section{Contrasting discourses, diverging perceptions}

In their official discourses, both China and Brazil frame their engagement in Mozambican agriculture through narratives of historically derived solidarity. However, the bases of this solidarity are different: while Brazilian policy actors express a sense of moral debt to Africa, China portrays itself as a longstanding partner against the colonial powers of the world.

Another commonality in official discourse is the emphasis on a shared experience of having been aid-recipient countries until recently. This gives both Brazil and China the moral authority to contrast their own claimed 'demand-driven' approaches with traditional donors' top-down and conditionality-heavy models. Particularly in China's case, however, resisting the idea of conditionality does not mean that aid does not require reciprocity: the explicit emphasis on 'win-win' provides a legitimating framework for the expectation of commercial or diplomatic advantage in return for development cooperation.

While both Brazil and China see development cooperation both as a foreign policy instrument and as a means to create economic opportunities, there are differences in emphasis. In Brazil's case, the discourse of 'solidarity diplomacy' highlights the fact that the country seeks diplomatic advantage from its cooperation engagements, but the picture is much less clear with regard to commercial advantage. While there is a strong emphasis on the purely 
technical nature of agricultural development cooperation among some Brazilian actors, others place an equally strong emphasis on its potential to open up investment opportunities. China, by contrast, has a more consistent discourse: the commercial aspects of development cooperation are emphasised as integral to what a wide range of Chinese actors see as a more effective, economically sustainable approach to agricultural development cooperation.

Both countries frame the agricultural development models they seek to share with Mozambique as based on their own successful development experience. Both sets of experience include a strong emphasis on the guiding role of the state and the complementary importance of private investment. But the nature of the agricultural transformations to which these factors contributed is very different. Brazil's highest-profile agricultural development success story is the transformation of the Cerrado - a land-extensive, labour-substituting, technologyand capital-intensive shift towards exportoriented agriculture. For China, the key achievement was the country's conquest of food security in a context of labour abundance but extreme land scarcity, via the leap in productivity achieved in cultivation of the country's main staple crop, rice.

The narratives deployed in both countries to explain these successes are also very different. China emphasises the hard-working virtues of its farmers, and their skill in making productive use of the scarce natural resources of the country's densely populated countryside. Brazil, by contrast, has a national narrative of pioneering gaúchos taming the wild and empty interior of the country's Centre-West. Both sets of narratives translate across into social imaginaries of Mozambican agriculture; Chinese development cooperation practitioners attribute Mozambique's low agricultural productivity to wasteful use of resources, while Brazilians are more inclined to emphasise the need for enterprising spirit and sustained investment to overcome the constraints imposed by geographical remoteness, natural hazards and poor infrastructure.

The self-affirming nature of these narratives means that both Chinese and Brazilians tend to believe that they have much to teach and little to learn. This somewhat contradicts the discourse of 'mutual learning' that is common among advocates of South-South cooperation. Brazil's agricultural development cooperation practitioners are happy to acknowledge what they have learned in the past from richer countries (especially the USA and Japan), but few if any of them recognise that they may have something to learn from Mozambican farmers or agricultural researchers.

Mozambican policy elites share with both Brazil and China an emphasis on technologically driven modernisation as the key to the future of agricultural development in the country. In addition, they see China and Brazil as important sources of capital as well as technology something they perceive as lacking in the cooperation models offered by established Northern donors. Mozambican government officials idealise both Chinese and Brazilian agricultural experience, with an emphasis on technology inputs for productivity increases. However, these idealising narratives are contested by Mozambican NGO and media discourses which sound a much more cautious and critical note on the potential for local farmers to benefit from Chinese and Brazilian involvement.

Mozambican frontline bureaucrats and farmers share some of the idealising discourses of their superiors, but they are also more inclined to emphasise differences between Brazilian and Chinese approaches. Perhaps due to the fact that their presence is currently linked exclusively to technical cooperation, a field in which they face significant administrative and budgetary constraints, the Brazilians are perceived as having less money than either the Chinese or a traditional donor like Japan. The Brazilians have attracted some criticism for delays in following through on their promises, while the Chinese have a reputation for acting quickly, unhampered by bureaucratic delays and procurement rules. The Chinese are also perceived as more commercially driven, not least because their 'sustainability model' includes charging for agricultural extension services that have traditionally been provided free in Mozambique, whether by the state or by international NGOs.

The perceived Chinese tendency to establish enclaves, which are often difficult for even 
Mozambican government officials to access, is contrasted unfavourably with Brazilian agricultural cooperation workers' perceived informality, flexibility and openness. Brazil's commitment to strengthening existing institutions, rather than China's preferred option for developing new standalone ones, is also welcomed, particularly by IIAM's staff who have acquired a powerful image of Embrapa as a model that their own institution should aspire to emulate. In day-to-day engagements with Mozambican farmers and frontline bureaucrats, language barriers are a major issue for Chinese agricultural cooperation. As a Portuguesespeaking country, Brazil benefits from an initial perception that Brazilian cooperation practices are better suited to Mozambican realities.

The perceptions of Mozambican actors directly involved in engagements with Chinese and Brazilian agricultural development cooperation are also shaped by a number of stereotypes that are current among the country's population as a whole. Brazil's image is favourably influenced by the pervasiveness of cultural products, along with a general perception of openness and affability. However, very few Mozambican farmers have as yet come into direct contact with Brazilians, particularly the 'pioneer farmers' who are lining up to export the Cerrado development model to Mozambique - a group perceived within Brazil less as easy-going good companions than as hardnosed tamers of the 'savage interior'. The Chinese are already present in Mozambique in much larger numbers, mostly working on construction projects but increasingly engaged in petty trading, natural resource exploitation and agriculture. Popular perceptions combine bemusement and suspicion fuelled by language barriers and rumours of strange social and

\section{Notes}

1 A longer version of this article is published as a Future Agricultures Consortium working paper (Chichava et al. 2013).

2 www.abc.gov.br/Projetos/CooperacaoSulSul/ Mocambique (accessed 5 April 2013).

3 www.bloomberg.com/apps/news?pid= newsarchive\&sid = awyJqqwvrPhU (accessed 3 April 2013).

4 http://agenciabrasil.ebc.com.br/noticia/201011-19/com-apoio-do-brasil-cna-aposta-emmocambique-como-grande-produdor-dealimentos (accessed 3 April 2013). dietary habits with admiration for their supposed qualities as hard workers who are prepared to get their hands dirty.

\section{Conclusion}

The differences in discourses justifying and framing interventions, and the range of perceptions at local level, all influence the development encounter. Yet at its core a particular politics is being played out. In many people's eyes, technical cooperation provides a platform for external investment, and the exploitation of Mozambique's agricultural potential through a diversity of partnerships. Both Chinese and Brazilian development cooperation and investment initiatives in agriculture chime with the interests of the political and business elite in Mozambique. An alliance of elite interests is thus formed, sometimes with Western donors involved in trilateral arrangements. Undoubtedly, foreign investment in the agricultural sector is needed in Mozambique, but questions of who gains, and who loses out are inevitably raised. A rush to external investment, especially in the context of large, area-based projects, such as ProSavana, has been questioned on multiple fronts. Will the benefits of such investments spread to the vast majority of poor, rural smallholder farmers? Will the technology development centres, pilot projects and extension efforts focused on smallholders be appropriate and well targeted? Or will local political and business elites, in alliance with external investors, be the main beneficiaries? Only time will tell what the distribution of outcomes will be, but Mozambique will certainly remain an important focus for the debate about future patterns of South-South cooperation in Africa, with the political dimensions of such encounters at the centre.

5 Interview with ProSavana focal person at FGV Projetos, 20 November 2012.

6 See www.pinesso.com.br/noticias/agronegocio/ agromoz-grupo-agricola-interessado-nacultura-de-milho-e-algodao-no-pais (accessed 3 April 2013).

7 Interview with ProSavana focal person at FGV Projetos, 20 November 2012.

8 Interview with FGV Projetos representative, São Paulo, 19 October 2012.

9 Website of Economic and Commercial Counsellor's Office of the Embassy of PRC in Mozambique http://mz.mofcom.gov.cn/ 
aarticle/jmxw/201111/20111107855636.html (accessed 3 April 2013).

10 Website of the Embassy of PRC in Mozambique, http://mz.chineseembassy.org/chn/zmgx/zmhz/ (accessed 3 April 2013).

11 These regions are Chokwe, in Gaza Province (southern Mozambique), Zambezi Valley, Zambezi Province (in the centre), and Nguri and Chipembe, in Cabo Delgado Province (northern Mozambique).

12 Ibid.

13 Interview with many ARPONE (Association of the Ponela Irrigation System) farmers and RBL employees, May 2012, Xai-Xai.

14 Interview with employee of HLMO in Xai-Xai, February 2012.

15 Interview with Senior Executive of CPI, Maputo, April 2012.

16 Interview with Counselor Minister from the Brazilian Embassy in Mozambique, 6 December 2011, Maputo.

17 Interview with Embrapa's General Coordinator, 17 July 2012, Maputo.

18 Ibid.

19 Interview with Counselor Minister from the Brazilian Embassy in Mozambique, 6 December 2011, Maputo.

\section{References}

ABC (2010) A Cooperação Técnica do Brasil ara a África, Brasília: Agência Brasileira de Cooperação

AMPA (2011) Pinesso Planta 10 mil Hectareas de Algodão no Sudão, www.ampa.com.br/home/ noticia/pinesso-planta-10-mil-hectares-dealgod\%C3\%A3o-no-sud\%C3\%A3o (accessed 19 November 2012)

Bias, C. (2012) 'ProSavana. Uma Oportunidade para o Desenvolvimento de Agronegócios no Corredor de Nacala', presentation delivered in March 2012, Maputo

Brautigam, D. and Ekman, S. (2012) 'Rumours and Realities of Chinese Agricultural Engagement in Mozambique', African Affairs 111.444: 483-92

CAAS (Chinese Academy of Agricultural Sciences) (2009) Green Super Rice for the Resource Poor in Africa and Asia (BMGF grant ID\#: 51587), Semi Annual Report submitted to the Bill \& Melinda Gates Foundation (BMGF) by Chinese Academy of Agricultural Sciences, July

Centre for Chinese Studies (2009) Patterns of Chinese Investment, Aid and Trade in Mozambique,
20 In the original Portuguese, 'Cerrado - nem dado nem herdado'.

21 Interview with representative of FGV Projetos, 20 November 2012, Maputo.

22 Interview with the National Director of Agriculture Services from MINAG, 9 February 2012, Maputo.

23 Ibid.

24 UNAC members have travelled to Brazil to meet the Brazilian NGOs and social movements and they were organising a meeting in Japan in March 2013.

25 Interview with the National Director of Agriculture Services in Maputo, 9 February 2012.

26 Ibid.

27 Interview with Technology Transfer Department of IIAM-Maputo, 17 February 2012.

28 Interview with local farmer from Xai-Xai and member of the Association of the Ponela Irrigation System (ARPONE), 18 October 2012, Xai-Xai.

29 Interview with the National Director of Agriculture Services, 9 February 2012, Maputo.

briefing paper prepared for World Wide Fund for Nature, October

Chichava, S. (forthcoming) 'Xai-Xai Chinese Rice Farm and Mozambican Internal Political Dynamics: A Complex Relation'

Chichava, S.; Duran, J.; Cabral, L.; Shankland, A.; Buckley, L.; Lixia, T. and Yue, Z. (2013) Chinese and Brazilian Cooperation with African Agriculture: The Case of Mozambique, FAC Working Paper 049, Brighton: Future Agricultures Consortium

CINDES (Centro de Estudos de Integração e Desenvolvimento) (2011) 'A África na Agenda Econômica do Brasil: Comércio, Investimentos e Cooperação', Breves CINDES 61, Rio de Janeiro: Centro de Estudos de Integração e Desenvolvimento

Classen, S.F. (2013) Analysis of the Discourse and Background of the ProSAVANA Programme in Mozambique - Focusing on Japan's Role, Tokyo: Tokyo University of Foreign Studies Costa Vaz, A. and Inoue, C. (2007) Emerging Donors in International Development Assistance: The Case of Brazil, Ottawa: IDRC (International Development Research Centre), Partnership \& Business Development Division 
Danqing, X. and Yongsheng, C. (2012)

'Xiangyang's First Overseas Investment of \$95 Million in Agricultural Project in Mozambique', Xiangyang Daily, http://en.xiangyang.gov.cn/publish/cbnews/ 201205/04/cb416_1.shtml (accessed 21 June 2012)

Direcção Provincial de Agricultura de Gaza [Gaza Provincial Directorate of Agriculture] (2010) Informe do Estágio de Cooperação entre Moçambique e República Popular da China em Gaza [Report on the Stage of Cooperation Between Mozambique and the Popular Republic of China in Gaza], Xai-Xai, 10 May

Direcção Provincial de Agricultura de Gaza [Gaza Provincial Directorate of Agriculture] (2008) Acordo de Gemelagem específica para a área da Agricultura entre a Direçãa provincial de Gaza e a Direç̧ão Provincial De Administração das Farmas Estatais de Hubei (Hubei Lianfeng Mozambique CO, LDA), para Execução do Projecto De Produção Agrícola Alimentar no Regadio de Xai-Xai [Agriculture Twinning Agreement between the Gaza Provincial Directorate of Agriculture and the Provincial Directorate of Hubei State Farms Administration (Hubei Lianfeng Mozambique CO, LDA) for the Execution of an Agri-Food Production Project in the Xai-Xai Irrigation scheme], Xai-Xai, 20 October

Duran, J. and Chichava, S. (2012) 'Centro de Investigação e Transferências de Tecnologias Agrárias de Umbeluzi. A Historia de um 'Presente' Chinês a Moçambique', in S. Chichava and C. Alden (eds), A Mamba e o Dragão, Maputo: Instituto de Estudos Sociais e Económicos and SAIIA (South African Institute of International Affairs)

The Economist (2012) 'The Miracle of the Cerrado', 26 August, www.economist.com/node/16886442 (accessed 30 November 2012)

Embrapa (2012) Moçambique: Apoio ao Sistema de Inovação no Setor Agropecuário, Brasília: Empresa Brasileira de Pesquisa Agropecuária

FOCAC (Forum on China-Africa Cooperation) (2006) Forum on China-Africa Cooperation Beijing Action Plan (2007-2009), www.focac.org/eng/ ltda/dscbzjhy/DOC32009/t280369.htm (accessed 11 February 2013)

Folha de São Paulo (2011) Moçambique Oferece Terra Para os Agricultores Brasileiros, www.agora.uol.com. br/brasil/ult 10102u959442.shtml (accessed 11 February 2012)

Ganho, A.S. (2012) 'A Terra e a Água Para os Novos Agro-Investimentos em Moçambique:
O Que está em Jogo?', III Conferência Internacional do IESE, Maputo: Instituto de Estudos Sociais e Económicos (IESE)

GdM (Governo de Moçambique) (2011) Matriz dos Projectos com a República Popular da China, Maputo: Governo de Moçambique

Hosono, A. and Hongo, Y. (2012) Cerrado Agriculture: A Model of Sustainable and Inclusive Development, Tokyo: Japan International Cooperation Agency

Hubei Daily (2012) 'Hubei Achieves Progress in Overseas Agricultural Development', 1 July, http://english.rikes.gov.cn/4/ 288/291/4085.html (accessed 21 July 2012)

Instituto Lula (2012) O Brasil tem um Débito de Solidariedade com a África', diz Lula em Entrevista ao Financial Times, www.institutolula.org/obrasil-tem-um-debito-de-solidariedade-com-aafrica-diz-lula-em-entrevista-ao-financialtimes/ (accessed 8 February 2013)

JICA (Japan International Cooperation Agency) and Oriental Consultants (2011) Preparatory Study on Triangular Cooperation Program for Agricultural Development of the African Tropical Savannah among Japan, Brazil and Mozambique (ProSavana JBM), Final Report, Tokyo: Japan International Cooperation Agency

Li, X.; Qi, G.; Tang, L.; Zhao, L.; Jin, L.; Guo, Z. and $\mathrm{Wu}, \mathrm{J}$. (2012) Agricultural Development in China and Africa: A Comparative Analysis, London: Routledge

Loureiro, G.L. (2012) Projeto ProSavana: Cooperação ou Cavalo-de-Tróia? A Ambiguidade da Presença Brasileira em África, Matutações, 6 July, http://matutacoes.wordpress.com/ 2012/07/06/projeto-prosavana-cooperacao-oucavalo-de-troia-a-ambiguidade-da-presencabrasileira-em-africa/ (accessed 17 December 2012)

Mabunda, L. (2012) 'O Governo Vendeu 24 Distritos a Brasileiros', O País, 19 August, www.opais.co.mz/index.php/opiniao/86-lazaromabunda/16037-governo-vendeu-24-distritosa-brasileiros.html (accessed 29 November 2012) MINAG (Ministry of Agriculture) (2012) Chokwe Agro-processing Complex, Maputo: Ministério da Agricultura

MINAG (Ministry of Agriculture) (2010a) Plano Estratégico para o Desenvolvimento do Sector Agrário (PEDSA 2011_2020), Maputo: Ministério da Agricultura

MINAG (Ministry of Agriculture) (2010b) Projecto Ancora de Implantação das Fábricas de Processamento e do Estabelecimento das Cinturas de 
Produtores, Maputo: Ministério da Agricultura, 7 July

Rafael, A. (2011) 'O Neocolonialismo Brasileiro em Moçambique', O País, www.opais.co.mz/ index.php/analise/92-adelson-rafael/ 16099-o-neocolonialismo-brasileiro-emmocambique.html (accessed 11 February 2012) Revista Macau (2011) 'Uma Plataforma entre Moçambique e Ásia', Revista Macau 24: 77-79

Rosário, D. (2012) From Negligence to Populism: An Analysis of Mozambique's Agricultural Political Economy, FAC Working Paper 034, Brighton: Future Agricultures Consortium Triangle of Central China (2012) Hubei Achieves Progress in Overseas Agricultural Development, http://english.rikes.gov.cn/4/288/291/4085.html, (accessed 30 November 2012)

UNAG (União Nacional de Camponeses) (2012) Pronunciamento da UNAC Sobre o Programa ProSavana, União Nacional de Camponeses, www.unac.org.mz/index.php/7-blog/39pronunciamento-da-unac-sobre-o-programaprosavana (accessed 17 December 2012)

Weinhold, D.; Killick, E. and Reis, E.J. (2011) Soybeans, Poverty and Inequality in the Brazilian Amazon, Munich Personal RePEc Archive (MPRA), Paper 29646: 1-26 